(C) 1984. The Genetical Society of Great Britain

\title{
NATURAL SELECTION ON THE COLOUR POLYMORPHISMS OF TRICHIA HISPIDA (L.)
}

\author{
P. R. SHELTON \\ Department of Genetics, University Park, Nottingham NG7 2RD
}

Received 21.vi.84

SUMMARY

\begin{abstract}
The land snail Trichia hispida (L.) is polymorphic for shell and mantle colour. Sixteen pairs of samples were collected from Nottinghamshire sites with contrasting backgrounds. In comparisons between the members of each pair, all the samples from darker habitats had a higher proportion of dark-mantled morphs, and most had a higher proportion of dark-shelled morphs. These highly significant associations between habitat and morph-frequency provide good evidence of natural selection acting on these colour polymorphisms.
\end{abstract}

\section{INTRODUCTION}

Snails of the genus Trichia Hartmann (formerly Hygromia Risso; subfamily Hygrominae: family Helicidae) offer promising material for the study of natural selection. There are at least two widely-distributed species ( $T$. striolata (Pfeiffer) and T. hispida (L.)), which are morphologically similar and which often occur together. They have simple polymorphic shell and mantle characters. In $T$. striolata the shell may be white, fawn or rufous, and the mantle light or dark (Cain, 1959a; Jones et al., 1974). T. hispida (which is slightly smaller and more globular in shape) is similarly polymorphic (Cameron and Redfern, 1976). The mantle pigmentation of $T$. striolata is simply inherited (Cain, 1959b).

In $T$. striolata the frequencies of shell and mantle morphs are known to vary with habitat, apparently responding to selection correlated with the background on which they live (Jones et al., 1974). Here I report on a similar study, on $T$. hispida, of the associations between morph frequencies and background. It shows that the species respond in a similar way, and suggests that comparisons between populations of the two species in sympathy would provide even more sensitive methods of detecting and measuring natural selection.

\section{Materials AND methods}

Sixteen pairs of populations of $T$. hispida were sampled during the summer of 1983 from alluvial soils in the Trent Valley to the east of Nottingham. T. striolata is absent from this area (Carr, 1916). The members of each pair were taken from sites with contrasting backgrounds, as close to each other as possible. The distances between members of pairs varied from 2 to $500 \mathrm{~m}$, the average was about $10 \mathrm{~m}$. Every shell observed was taken. The sampling area was kept as small as possible $\left(0 \cdot 2-14 \cdot 0 \mathrm{~m}^{2}\right)$. The living snails were scored for shell and mantle colour. The shell colour was either dark rufous (var. rosea of Taylor, 1916) or the more typical light fawn colour. No colourless shells (var. albida) were found. The mantle colour was either pale with occasional dark spots or almost entirely black. 
The scoring of shell colour was made consistent by comparison with "standard" shells of each colour. The background and vegetation at each site were recorded, and the members of each pair were scored as "darker" or "lighter" in background relative to each other.

\section{Results}

The results of the survey are presented in table 1 . There is an association between morph frequency and background (fig. 1). If the lighter habitat

TABLE 1

Composition of samples of $\mathrm{T}$. hispida

\begin{tabular}{|c|c|c|c|c|c|c|c|c|c|c|}
\hline & \multirow[b]{2}{*}{$\begin{array}{l}\text { Grid } \\
\text { ref* }\end{array}$} & \multirow[b]{2}{*}{$\begin{array}{l}\text { Total } \\
\text { live } \\
\text { snails }\end{array}$} & \multicolumn{4}{|c|}{ Composition of samples } & \multirow[b]{2}{*}{$\begin{array}{c}\% \\
\text { Dark } \\
\text { body }\end{array}$} & \multirow[b]{2}{*}{$\begin{array}{c}\% \\
\text { Dark } \\
\text { shell }\end{array}$} & \multirow[b]{2}{*}{ Habitat } & \multirow[b]{2}{*}{ Background } \\
\hline & & & $\begin{array}{c}\text { Dark } \\
\text { body, } \\
\text { dark } \\
\text { shell }\end{array}$ & $\begin{array}{l}\text { Dark } \\
\text { body, } \\
\text { light } \\
\text { shell }\end{array}$ & $\begin{array}{c}\text { Light } \\
\text { body, } \\
\text { dark } \\
\text { shell }\end{array}$ & $\begin{array}{c}\text { Light } \\
\text { body, } \\
\text { light } \\
\text { shell }\end{array}$ & & & & \\
\hline \multirow[t]{2}{*}{1.} & 543382 & 32 & 18 & 1 & 6 & 7 & $59 \cdot 4$ & $75 \cdot 0$ & $\mathbf{M}$ & Darker \\
\hline & 543382 & 35 & 7 & 0 & 11 & 17 & $20 \cdot 0$ & $51 \cdot 4$ & $\mathrm{~N}$ & Lighter \\
\hline \multirow[t]{2}{*}{2.} & 662453 & 26 & 5 & 3 & 8 & 10 & $30 \cdot 8$ & $50 \cdot 0$ & $\mathrm{~L}$ & Darker \\
\hline & 662453 & 44 & 6 & 3 & 13 & 22 & $20 \cdot 5$ & $43 \cdot 2$ & B & Lighter \\
\hline \multirow[t]{2}{*}{3.} & 627452 & 39 & 18 & 0 & 7 & 14 & $46 \cdot 2$ & $64 \cdot 1$ & $\mathbf{R}$ & Darker \\
\hline & 627452 & 23 & 8 & 1 & 5 & 9 & $39 \cdot 1$ & $56 \cdot 5$ & $\mathrm{~L}$ & Lighter \\
\hline \multirow[t]{2}{*}{4.} & 528350 & 41 & 16 & 23 & 0 & 2 & $95 \cdot 1$ & 39.0 & $\mathbf{R}$ & Darker \\
\hline & 528345 & 18 & 1 & 2 & 0 & 15 & $16 \cdot 7$ & $5 \cdot 6$ & $\mathbf{N}$ & Lighter \\
\hline \multirow[t]{2}{*}{5.} & 657447 & 22 & 11 & 1 & 3 & 7 & $54 \cdot 5$ & $63 \cdot 6$ & $\mathbf{R}$ & Darker \\
\hline & 657447 & 21 & 4 & 0 & 10 & 7 & $19 \cdot 0$ & $66 \cdot 7$ & $\mathrm{~L}$ & Lighter \\
\hline \multirow[t]{2}{*}{6.} & 682437 & 30 & 20 & 4 & 1 & 5 & $80 \cdot 0$ & $70 \cdot 0$ & $\mathbf{N}$ & Darker \\
\hline & 682437 & 49 & 16 & 23 & 4 & 6 & $79 \cdot 6$ & $40 \cdot 8$ & $\mathbf{R}$ & Lighter \\
\hline \multirow[t]{2}{*}{7.} & 541349 & 18 & 9 & 5 & 2 & 2 & $77 \cdot 8$ & $61 \cdot 1$ & $\mathbf{M}$ & Darker \\
\hline & 542349 & 21 & 3 & 3 & 3 & 12 & $28 \cdot 6$ & $28 \cdot 6$ & $\mathrm{~L}$ & Lighter \\
\hline \multirow[t]{2}{*}{8.} & 524350 & 14 & 7 & 2 & 4 & 1 & $64 \cdot 3$ & $78 \cdot 6$ & $\mathbf{M}$ & Darker \\
\hline & 524350 & 13 & 4 & 2 & 5 & 2 & $46 \cdot 1$ & $69 \cdot 2$ & $\mathbf{M}$ & Lighter \\
\hline \multirow[t]{2}{*}{9.} & 530352 & 18 & 12 & 6 & 0 & 0 & $100 \cdot 0$ & $66 \cdot 7$ & $\mathbf{R}$ & Darker \\
\hline & 530352 & 8 & 4 & 3 & 0 & 1 & $87 \cdot 5$ & $50 \cdot 0$ & $\mathbf{R}$ & Lighter \\
\hline \multirow[t]{2}{*}{10.} & 528329 & 8 & 7 & 0 & 1 & 0 & $87 \cdot 5$ & $100 \cdot 0$ & $\mathbf{M}$ & Darker \\
\hline & 528330 & 10 & 6 & 1 & 0 & 3 & $70 \cdot 0$ & $60 \cdot 0$ & $\mathbf{M}$ & Lighter \\
\hline \multirow[t]{2}{*}{11.} & 572353 & 26 & 12 & 5 & 4 & 5 & $65 \cdot 4$ & $61 \cdot 5$ & $\mathbf{N}$ & Darker \\
\hline & 572353 & 8 & 0 & 0 & 4 & 4 & 0.0 & 50.0 & B & Lighter \\
\hline \multirow[t]{2}{*}{12.} & 559366 & 9 & 2 & 3 & 0 & 4 & $55 \cdot 6$ & $22 \cdot 2$ & $\mathbf{N}$ & Darker \\
\hline & 559366 & 18 & 1 & 1 & 4 & 12 & $11 \cdot 1$ & $27 \cdot 8$ & $\mathrm{~L}$ & Lighter \\
\hline \multirow[t]{2}{*}{13.} & 616324 & 33 & 15 & 5 & 4 & 9 & $60 \cdot 6$ & 57.6 & $\mathbf{R}$ & Darker \\
\hline & 616324 & 17 & 3 & 2 & 3 & 9 & $29 \cdot 4$ & $35 \cdot 3$ & B & Lighter \\
\hline \multirow[t]{2}{*}{14.} & 598374 & 16 & 4 & 1 & 3 & 8 & $31 \cdot 3$ & $43 \cdot 8$ & $\mathbf{N}$ & Darker \\
\hline & 598374 & 17 & 2 & 3 & 6 & 6 & $29 \cdot 4$ & $47 \cdot 1$ & $\mathrm{~L}$ & Lighter \\
\hline \multirow[t]{2}{*}{15.} & 650403 & 37 & 17 & 6 & 6 & 8 & $62 \cdot 2$ & $62 \cdot 2$ & $\mathbf{R}$ & Darker \\
\hline & 650403 & 14 & 3 & 2 & 5 & 4 & $35 \cdot 7$ & $57 \cdot 1$ & $\mathbf{N}$ & Lighter \\
\hline \multirow[t]{2}{*}{16.} & 691334 & 14 & 6 & 1 & 2 & 5 & $50 \cdot 0$ & $57 \cdot 1$ & $\mathbf{R}$ & Darker \\
\hline & 691334 & 13 & 3 & 3 & 4 & 3 & $46 \cdot 2$ & $53 \cdot 8$ & $\mathbf{R}$ & Lighter \\
\hline
\end{tabular}




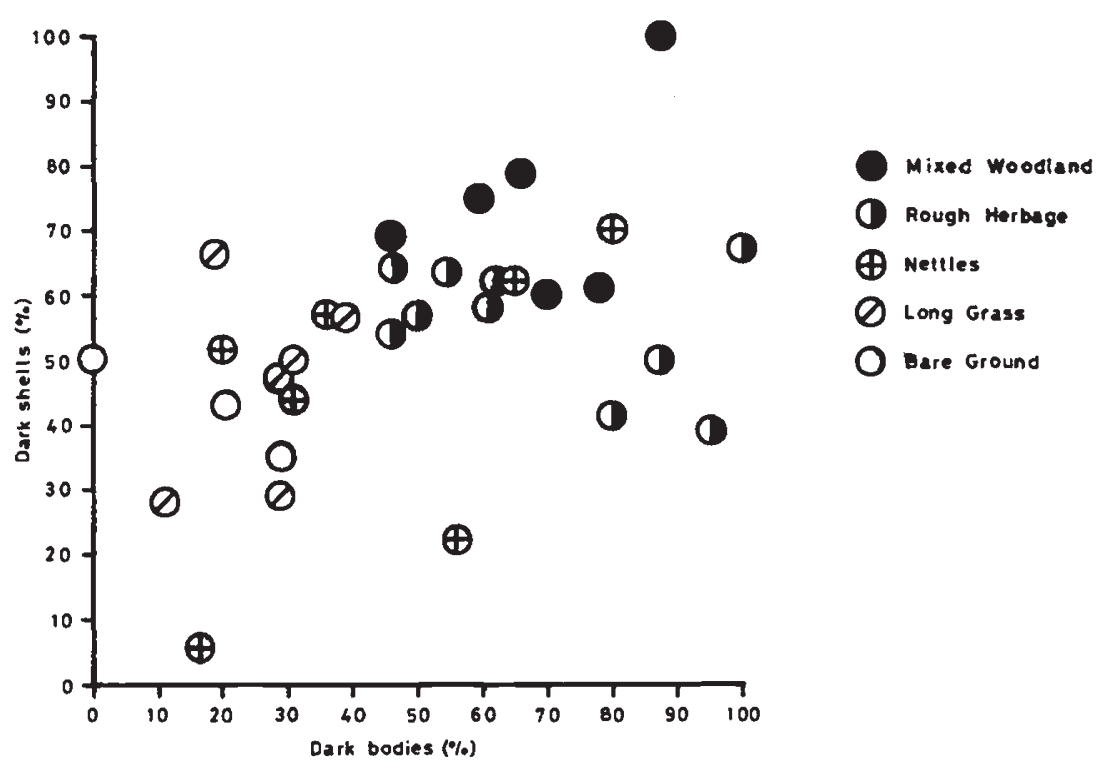

FIG. 1. Association between morph frequency and habitat in populations of Trichia hispida.

types ("long grass" and "bare ground") are compared to the darker habitats ("rough herbage" and "mixed woodland") there is a significant tendency for there to be a higher proportion of both dark shells and dark bodies in the darker habitats $(p<0.001$ for bodies, $p<0.01$ for shells). Taking only "long grass" as representative of light habitats and "rough herbage" as representative of dark habitats the association between dark bodies and dark habitats remains significant $(p<0.01)$ but the association is no longer significant for shells $(p=0 \cdot 24)$. With "mixed woodland" representing dark habitats the divergence from "long grass" is significant for both shells and bodies $(p<0.02$ in both cases). These results suggest that there may be a stronger habitat-related selection for body colour than for shell colour.

Nettle populations show no consistency in morph frequency, perhaps because nettles indicate recent disturbance, and because such sites have very different backgrounds at different times of the year.

In 13 of the 16 pairs of samples the darker site shows a higher frequency of dark shells than the associated lighter site. The difference is significant $(p<0.01)$ by the median test. When the size and direction of the differences are taken into account by summing chi (Haldane's method: Quenouille, 1950) the difference is highly significant:

$$
\sum\left(\frac{\chi}{n}\right)^{2}=15 \cdot 0, \quad p<10^{-5} \text {. }
$$

At all 16 sites the frequency of dark bodied snails is greater at the darker site than at the lighter site. The difference is highly significant $(p<0.001)$ by the median test, and by Haldane's method $\left(p<10^{-7}\right)$.

Overall, the frequencies of dark shell and dark body are positively correlated $(r=0.48, p<0.01)$, as would be expected from their joint associations with habitat type. 


\section{Discussion}

Trichia hispida shows an association morph frequency with background and habitat similar to that found in T. striolata (Jones et al., 1974), Cepaea nemoralis (Cain and Sheppard, 1954), C. hortensis (Clarke, 1962), and Arianta arbustorum (Parkin, 1971). That is, darker morphs are more frequent in darker habitats. This suggests that visual selection is acting against visually inappropriate morphs. T. hispida is often eaten by birds (Taylor, 1916), although few shells predated by rodents or broken by birds were found, perhaps because the snails are being eaten whole. Many dead snails were found with an insect larva in the decaying body, so that it appears that there is at least one insect predator or parasite that attacks $T$. hispida.

Under these conditions of strongly directional selection one might expect that populations would become fixed for the most advantageous morph in each habitat. As the populations remain polymorphic, there may be some form of balancing selection (see Clarke 1975 for possible mechanisms), or immigration from other habitats.

Within 26 of the 32 samples there is an excess of two morph combinations (dark body-dark shell, and light body-light shell). The excess of these morph types was also noted by Cain $(1959 a)$ in $T$. striolata. In 5 samples the excesses of light-light and dark-dark is significant at the 5 per cent level. When the size and direction of all the differences is taken into account over all the samples the significance is great (Haldane's test: $p<10^{-7}$ ). This might result from the close linkage of the genes for body and shell colours and concomitant linkage disequilibrium, as suggested by Cain (1959b) for T. striolata.

There is some evidence of regional differences in phenotype frequency, perhaps analogous to the "area effects" of Cain and Currey (1963). There is a significant decrease in the frequency of dark shells with distance from the river (or height above the river). The test for the significance of the regression assumes that the observations are independent of each other, an assumption that is almost certainly invalid (see Sokal and Oden, 1978). While the association may therefore be spurious, it is possible that there is an "area effect" for shell colour with one area lying alongside the river, and another displaced from it. There is no evident relationship between location and body colour.

Since there is no obvious geographical pattern in the distribution of the different habitat types, the associations between morph-frequency and habitat are very unlikely to be artifacts. These observations thus provide good evidence that natural selection acts on the colour polymorphisms in $T$. hispida. The selective agents are not known, although by analogy with Cepaea and Arianta, likely candidates are predatory birds selectively killing those morphs that stand out against their background (Cain and Sheppard, 1954; Parkin, 1971).

Acknowledgements. I am grateful to Professor B. C. Clarke both for the opportunity to undertake this research and for his supervision, advice and criticism. I would like to thank Dr D. T. Parkin for much stimulating discussion during the project, and Dr R. A. D. Cameron for his help with species identification. 


\section{References}

CAIN, A. J. 1959a. An undescribed polymorphism in Hygromia striolata (C. Pfeiffer). J. Conch., 24, 319-322.

CAIN, A. J. 1959b. Inheritance of mantle colour in Hygromia striolata (C. Pfeiffer). J. Conch., 24, 352-353.

CAIn, A. J. And Currey, J. D. 1963. Area effects in Cepaea. Phil. Trans. Roy. Soc. Lond., B, 246, 1-81.

CAIN, A. J. AND SHEPPARD, P. M. 1954. Natural selection in Cepaea. Genetics, 39, 89-116.

CAMERON, R. A. D. AND REDFERN, M. 1976. British Land Snails. Synopses of the British Fauna No. 6. The Linnean Society, Academic Press, London.

CARR, J. W. 1916 The Invertebrate Fauna of Nottinghamshire. Notts. Natur. Soc., J. \& H. Bell, Nottingham.

CLARKE, B. 1962. Natural selection in mixed populations of two polymorphic snails. Heredity, $17,319-345$.

CLARKE, B. 1975. The contribution of ecological genetics to evolutionary theory: detecting the direct effects of natural selection on particular polymorphic loci. Genetics, 79, 101-113.

JONES, J. S., BRISCOE, D. A. AND CLARKE, B. 1974. Natural selection on the polymorphic snail Hygromia striolata. Heredity, 33, 102-106.

PARKIN, D. T. 1971. Visual selection in the land snail Arianta arbustorum. Heredity, 26, 35-47. QUENOUILlE, M. H. 1950. Introductory Statistics. Pergamon Press, London.

SOKAL, R, R. AND ODEN, N. L. 1978. Spatial autocorrelation in biology. 2. Some biological implications and four applications of evolutionary and ecological interest. Biol. J. Linn. Soc. 10, 229-249.

TAYLOR, J. W. 1916. Monograph of the Land and Freshwater Mollusca of the British Isles. Taylor Bros., Leeds. 